DOI: 10.19195/0137-1150.163.64

\author{
EWA STAWCZYK \\ Uniwersytet Gdański, Polska \\ fpoes@univ.gda.pl
}

\title{
Piękno starości. Poetycki obraz przemijania w prozie Gorana Petrovicia
}

Niewiele jest starości w prozie Gorana Petrovicia, mimo że jest w niej bardzo dużo śmierci. Bohaterowie, jeśli już umierają, czynią to bez zbędnego ociągania, na ogół kontynuując swoje istnienie w innym, nadnaturalnym wymiarze, nierzadko w przestrzeni snu. W starości nie ma przecież ani wzniosłości, ani tajemnicy, jakże często nie ma w niej także godności — i może dlatego, mimo iż posunięcie to jest bardziej drastyczne, lepiej jest bohaterów uśmiercać od razu niż skazywać ich na wielostronicowe starzenie się. Potrzeba wielkiej wrażliwości i sprawnego pióra, by w starości dostrzec piękno i umieć je opisać, nie ocierając się o banał. Sztuka ta udała się serbskiemu pisarzowi, który wykorzystując między innymi silnie zmetaforyzowany język, posługując się ciepłymi barwami, zilustrował z wyczuciem starość. Poprzez umiejętne stosowanie ornamentalnego języka nacechowanego tropami poetyckimi, autor w niezwykle subtelny sposób przenosi czytelnika w odrealnioną, oniryczną i wyidealizowaną rzeczywistość, pokazując jednocześnie starzejących się bohaterów i starzejący się wraz z nimi świat, który bezpowrotnie przemija.

Jeden z piękniejszych obrazów starości obecnych w prozie Petrovicia znajduje się w opowiadaniach ze zbioru Ostrvo i okolne priče (1996) oraz w powieści Sitničarnica „Kod srećne ruke” (2000), wydanej również w Polsce w 2006 roku pod tytułem Sklepik „Pod Szczęśliwa Ręką" . W obu przypadkach starość nie jest przedstawiana pod postacią archetypicznego starca-mędrca ${ }^{2}$, lecz kryje się w obrazie poczciwego staruszka. Zamiana ta nie dotyczy jedynie aspektu leksykalnego, lecz przede wszystkim semantycznego. Staruszkowie Petrovicia to

${ }^{1}$ G. Petrović, Sklepik „Pod Szczęśliwa Ręką”, przeł. M. Duškov, Torun 2006.

2 Obraz mądrego starca, często podróżnika, pojawia się w innych utworach G. Petrovicia, czego przykładem może być chociażby postać św. Symeona z powieści Opsada crkve Svetog Spasa (1997). 
pogodni, serdeczni i wzbudzający sympatię bohaterowie. Zredukowani w swoim literackim opisie do życzliwych i prostodusznych istot, stanowią bądź żywe przykłady zanikającego folkloru (Ostrvo i okolne priče), bądź też są nośnikiem starych tradycji (Sitničarnica „Kod srećne ruke”). Na próżno szukać w ich wyglądzie oznak brzydoty starczego ciała czy też jakiegokolwiek fizycznego zniedołężnienia. Petrović pomija te kwestie nie tyle z troski o estetyczną wrażliwość czytelnika, ile przede wszystkim z chęci odrealnienia postaci, spotęgowania odczucia onirycznej rzeczywistości ich świata. Nie ma u Petrovicia starości szpetnej i kalekiej, o której pisał z taką zaciętością chociażby Arystoteles ${ }^{3}$. Starość, której brzydoty i ułomności się nie dostrzega, to w utworach serbskiego autora stan pewnego zawieszenia, egzystencji poza czasem i przestrzenią. Na ten wyidealizowany obraz starości, oprócz celowego pomijania nieestetycznych jej aspektów, ma wpływ jeszcze kilka innych czynników. Najważniejszym w nich jest użycie silnie zmetaforyzowanego języka.

Idealizację świata, w którym żyją staruszkowie Petrovicia, za pomocą zabiegów stylistycznych i metaforyzacji języka widać najwyraźniej w opowiadaniach Šest listova smilja czy Trska, ze wspomnianego tomu Ostrvo i okolne priče. Utrzymane są one w konwencji nadrealistycznej, balansującej na granicy irrealnej fantazji dziecięcej i filozoficzno-artystycznej kreacji. Bohaterowie, para staruszków żyjących na wsi, przedstawieni są podczas wspólnych posiłków czy prac domowych, kiedy to wekują w słoikach słońce na zimę, rozczesują zbyt gęste promienie słońca, by nie wypaliły sadzonek w ogrodzie, wkładają uśmiechy do kieszeni przed wyjściem z domu bądź zawieszają w oknach co wieczór zasłony mroku, nakrywają stół czystością albo z nudów pogryzają słomki porannego światła lub też zbierają sny i związane księżycowym blaskiem wieszają pod strzechą na czarną godzinę.

Świat innej staruszki, pani Nataliji Dimitrijević z powieści Sitničarnica „Kod srećne ruke” też jest idealizowany za pomocy metaforycznego przesunięcia znaczenia z jednego wyrazu na drugi, semantycznie od niego odległego, co automatycznie wydobywa poetyckie zabarwienie całego fragmentu. Pani Dimitrijević spędza ze swoją opiekunką czas przy słabiutkiej, niesłodzonej herbacie, mocząc w niej połamane, zeszłoroczne lamentowania. Rozmowy upływają obu paniom pod znakiem kandyzowanych przychylności czasem osłodzonych sma-

${ }^{3}$ Wyraz swojej niechęci do osób w podeszłym wieku i krytyczne spojrzenie na starość odnaleźć można w licznych dziełach Arystotelesa, m.in. w Etyce nikomachejskiej czy Retoryce (oba teksty powstałe w IV w p.n.e.). Pisząc o osobach starszych, Arystoteles zauważa, że „są nieżyczliwi, zła wola przejawia się bowiem w dostrzeganiu we wszystkim gorszych stron" — stwierdzenie to należy do jednych z łagodniejszych w tonie pośród znacznie ostrzejszych tego autora (Arystoteles, Retoryka. Poetyka, przeł. H. Podbielski, Warszawa 1988, s. 187). Szerzej o poglądach Arystotelesa na temat starości zob. m.in. K. Pawełczyk, Starość w czasie i przestrzeni. Modele starości na wybranych przykładach kulturowych, [w:] Starość: doświadczenie egzystencjalne, temat literacki, metafora kultury, seria I. Rozpoznania, red. A. Janicka, E. Wesołowska, G. Kowalski, Białystok 2013, s. 69-90. 
kiem komplementów, a wraz z ciasteczkami podawane są na stół rodzinne wspomnienia. Funkcja kreacyjna metafory polega tutaj na połączeniu dość nieoczekiwanego składnika leksykalnego z członem przywodzącym na myśl zupełnie inne konkretne skojarzenie. Oryginalność tego zabiegu kryje się w tym, że odległe semantycznie człony powstałych zestawień łączy wspólny czynnik sytuacyjny. Następuje tu niejako pewien poetycki skrót myślowy, mający postać kontekstowego zrostu, powstałego $\mathrm{w}$ wyniku trwałego połączenia różnych elementów w jedną całość. Zamiast maczać w herbacie biszkopty i lamentować podczas jej picia, można pić herbatę, maczając w niej lamentowania. Czytelnik uzmysławia sobie sens takiej wypowiedzi, łącząc znaczenie poszczególnych słów z kontekstem, odkrywając prawdziwą moc metafory, która jest - cytując Aleksandrę Okopień-Sławińską — „wyrażeniem o pozornej niespójności semantycznej, wypróbowującym nową łączliwość kontekstową i w ten sposób pobudzającym mechanizm znaczeniotwórczy"4 . Metaforyzacja utworów Petrovicia - jak zauważa Sylwia Nowak-Bajcar - jest „oparta na zamianie cech i właściwości nie tylko pojedynczych elementów świata przedstawionego, ale też całych jego struktur poprzez wypełnienie przestrzeni codzienności elementami przynależącymi do świata wyobraźni lub poprzez zastąpienie porządku przestrzennego porządkiem temporalnym"5.

Poetyzacja tekstu poprzez antropomorfizację przedmiotów martwych i częste użycie metafor, które jednak występują tu w postaci udosłownionej, wywołuje w czytelniku poczucie oniryczności i nierealności tego świata. Należy w tym miejscu zaznaczyć, że przy klasycznej poetyzacji tekstu prozatorskiego mamy do czynienia z odrealnieniem na poziomie stylistycznym, w przypadku zaś udosłownienia metafory $\mathrm{w}$ prozie Petrovicia odrealnienie to rodzi się na poziomie ontologicznym, albowiem odwołując się do słów amerykańskiego badacza Briana McHale'a, ,konfrontuje to, co jest empirycznie dane w naszym świecie, z czymś, co dane nie jest, co pochodzi spoza świata lub go przekracza"6, jednocześnie nadając mu status ontologiczny. Udosłownienie metafor w opowiadaniach serbskiego autora jest niewątpliwie głównym czynnikiem kreującym ich sielankową rzeczywistość. Dodatkowo, poprzez specyficzną, trochę naiwną narrację, prowadzoną często z perspektywy dziecka (Śest listova smilja oraz Trska), rzeczywistość ta zyskuje wymiar, w którym realistyczne i oniryczne elementy tworzą monolityczną jedność.

Zbudowany na metaforze świat bohaterów odbija się również w samych postaciach. Staruszkowie wpisują się w stereotypowy, jakże często spotykany w bajkach ludowych obraz stareńkich, wyrozumiałych i dobrotliwych dziadków, których czytelnik widzi przez pryzmat własnych doświadczeń z dzieciństwa. Co-

${ }^{4}$ A. Okopień-Sławińska, Metafora bez granic, [w:] Studia o metaforze, 2, red. M. Głowiński, A. Okopień-Sławińska, Wrocław 1983, s. 38.

5 S. Nowak-Bajcar, Mapy czasu. Serbska proza postmodernistyczna wobec wyzwań epoki, Kraków 2010, s. 155-156.

${ }^{6}$ B. McHale, Powieść postmodernistyczna, przeł. M. Płaza, Kraków 2012, s. 85. 
dzienne, zwykłe czynności staruszków urastają w utworach Petrovicia do rangi małych rytuałów, a ich wykonywaniu towarzyszy wyjątkowa wręcz celebracja. Czynności te nie tylko organizują życie bohaterom, lecz także stanowią w nim pewien constans, punkt odniesienia. Związane ściśle z porą dnia czy roku czynności takie, jak robienie weków, suszenie ziół na zimę czy też popołudniowe sączenie herbaty, to elementy starego porządku, na które brakuje czasu w świecie młodych ludzi. W przypadku opowiadań z tomu Ostrvo i okolne priče są to także ilustracje idyllicznego życia na wsi, któremu przeciwstawiane jest życie młodych w mieście. Opisy sielskich krajobrazów, wyjęte niczym z obrazów serbskich malarzy naiwnych, z małymi, wtulonymi w piękne wzgórza domkami, na których gankach siedzą pogodni dziadkowie, to wyraz celowej mityzacji wsi i pochwały etosu ludowego, a sami staruszkowie, mówiący językiem pełnym ludowych mądrości („Ne plači u senci, opasno je, pristaće ti mahovina na trepavice”7 czy „Gost u kuću, kao so u stupu"8) idealnie wpisują się w tę konwencję. Można wręcz powiedzieć, że starość w tych opowiadaniach ubrana jest w strój ludowy i zamieszkuje w skansenie, będącym skupiskiem ładnie prezentowanych staroci, pozostałości po minionych czasach.

Idylliczny i wykreowany za pomocą licznych metafor oniryczny świat staruszków powoli kurczy się i ustępuje miejsca surowej rzeczywistości młodych. W jednym z opowiadań zatytułowanym Trska dziadek zabiera wnuczka na pobliskie wzgórze, aby pokazać mu, gdzie leży granica między światem, w którym żyją staruszkowie (będącym w rzeczywistości przestrzenią snu), a tym, który go otacza i powoli pochłania (jawą). Podczas spaceru oczom chłopca ukazuje się dobrze widoczna linia oddzielająca naturalnie piękny, wiejski krajobraz od brudnej, ciemnej i niedoskonałej pod każdym względem uprzemysłowionej przestrzeni miasta.

Po sredini susednog brda uočavao sam granicu. U donjem kraju, bukova šuma beše proređena, nekako strnula. U gornjem se zelenela, zakleo bih se da joj nije nedostajao jedan jedini listak. Uopšte, sve iznad linije dodira sna i jave beše punije. Nebo je bilo jasno. Planine poput rtova u plavom. Ptičja jata kao pena što se sakuplja čas tu, čas tamo.

Sve ispod linija dodira sna i jave, međutim, beše u velikom neredu. Bez ikakve sumnje, u nekada lepu dolinu, bujica jave je nanela gomile bespotrebnih stvari. Krtičnjaci kuća su ružili polja. Metalni mostovi su grubo uzili zemlje?

Przestrzeń snu wypełniona jest niezanieczyszczoną jeszcze naturą w swej najpiękniejszej i najczystszej postaci. Idealny krajobraz ,jak ze snu” przywołuje na myśl obrazy rajskich ogrodów, do których człowiek dawno utracił dostęp, lecz nie przestał o nich śnić. W przeciwieństwie do snu jawa ukazana jest jako świat zepsuty, bo zurbanizowany, w pewnym sensie niepełny, bez jasnych, nasyconych barw, dotknięty szpetotą. Opowiadając o pięknie onirycznego świata, starszy

\footnotetext{
${ }^{7}$ G. Petrović, Ostrvo i okolne priče, Beograd 2002, s. 14.

8 Ibidem, s. 15.

${ }^{9}$ Ibidem, s. 23.
} 
mężczyzna wyjawia chłopcu także swój sekret. Staruszek nie może oddychać powietrzem jawy, której poziom tak wzrósł, że sięgająca niegdyś kolan, teraz kończy się sporo ponad głowami bohaterów. By się w niej nie utopić, dziadek używa długiej na kilka metrów słomki trzcinowej, za pomocą której może zaczerpnąć nieco powietrza snu. Podwyższający się poziom jawy oznacza coraz wyższy pułap, na który wypychany jest świat bohaterów. Przepełniona folklorem rzeczywistość zaplatania promieni słonecznych $\mathrm{w}$ warkocze $\mathrm{w}$ upalne letnie popołudnia to świat, który przynależny staruszkom starzeje się razem z nimi i ustępuje pola bezwzględnej jawie. Świat odrealnionej, ale i oswojonej przestrzeni, sam stanowi również metaforę pięknej starości.

Podobny obraz pogodnej staruszki, żyjącej we własnym świecie i wraz z nim przemijającej, odnaleźć można także w powieści Sitničarnica „Kod Srećne Ruke”, której jedną z bohaterek jest cierpiąca na chorobę Alzheimera, wspomniana już wcześniej, Natalija Dimitrijević. W opisie Nataliji nie doszukamy się niczego szczególnego ponad typowe z racji jej wieku upodobania do eleganckich strojów czy herbaty jaśminowej pitej z porcelanowych filiżanek. Dotknięta nie tylko chorobą ciała, lecz także samotnością kobieta umieszcza w gazecie anons o treści: „starijoj gospođi, potrebna pomnija družbenica" ${ }^{10}$. Bohaterka przedstawiona jest jako drobna kobieta, nosząca sukienki z surowego jedwabiu o dawnym kroju i podwójny sznur pereł u szyi, która, obowiązkowo w kapeluszu i nicianych rękawiczkach, spędza większość czasu w swoim pokoju bibliotecznym. Uczucie narastającej melancholii i osamotnienia najpełniej ilustruje fragment opisujący panią Nataliję właśnie w tym pomieszczeniu, przyrównanym do magicznego ogrodu:

Držeća starica je ovde ulazila otirući cipele o prostirku u hodniku. Svečano odevena, onako kako bi drugi izlazili o slavljima, sa obaveznim šeširom i končanim rukavicama. Da tek dokono sanjari, kao u zagonetnom hladu hiljadulisne senice. Ili da strpljivo pazi na svoje leje i krošnje, da boluje kraj kakvog upražnjenog mesta, kao okraj odstranjene grane, da razabere svaki mladar, da osunča i pretrebi davna, zaklonjena izdanja, da prhke listove brižljivo štiti od bolesti opadanja, da prignuvši glavu osluhne čuje li se, i gde, šušljanje knjigolaža [... $]^{11}$

Bohaterka podejmuje walkę z chorobą, by ocalić wspomnienia. Żyje w osamotnieniu (,samujem godinama..."12 — mówi bohaterka), ale wśród książek, będących szczególnymi pamiętnikami. Petrović także w tym przypadku posługuje się metaforą, by w poetycki sposób, słowami opiekującej się panią Nataliją Jeleny, opisać starość i towarzyszącą jej chorobę. „Jelena nađe da se gospođa još više smanjila, da se sabrala u smežurak života. Haljina davnog kroja, došla je kao svenula mahuna. I to potresno svedočanstvo nerazmrsive starosti ujedno duboko ganu i uznemiri devojku"13.

\footnotetext{
10 G. Petrović, Sitničarnica „,Kod Srećne Ruke”, Beograd 2005, s. 29.

11 Ibidem, s. 32.

12 Ibidem, s. 33.

13 Ibidem, s. 34.
} 
Starzejącej się pani Nataliji zaczyna dokuczać trapiąca ją bezsenność, a wraz z osadzającym się na bohaterce czasem pojawia się także znacznie poważniejszy problem, a mianowicie kłopoty z pamięcią. Coraz więcej wspomnień ulatuje z jej głowy i coraz więcej wysiłku musi wkładać, by o czymś nie zapomnieć. Wspólnie z zatrudnioną w charakterze „współtowarzyszki” Jeleną czyta książki, a dzięki lekturze przenosi się do Belgradu jej wspomnień, miasta, które całkowicie zmieniło swoją topografię i które istnieje już tylko w wymiarze tekstowym, w czytanych książkach.

Pamięć starego człowieka ${ }^{14}$ jest jednocześnie formą pamiętnika i albumu ze zdjęciami. Przechowalnią i podręczną szufladą biurka, do której — jak by się mogło wydawać — w każdej chwili można sięgnąć. W konstrukcji bohaterki Sklepiku... Petrović zwraca uwagę na dwa aspekty starzenia się. Jednym z nich jest życie wspomnieniami i we wspomnieniach; drugim — problem zapominania, z czasem również i samych wspomnień, które z biegiem lat tracą na ostrości.

„We wspomnieniu istnieje rodzaj magii, na którą jesteśmy wrażliwi niezależnie od wieku" 15 — pisała Simone de Beauvoir i nie sposób się z tym stwierdzeniem nie zgodzić. Wspomnienie bowiem przenosi nas w inną, zamkniętą w czasie i minioną rzeczywistość, najczęściej w przestrzeń naszej młodości. Dla obciążonego postępującą chorobą umysłu pani Dimitrijević lektura książek stanowi jedyną ścieżkę dostępu do własnych wspomnień. Czytając, bohaterka faktycznie wchodzi w przestrzeń tekstu, a wspomnienia, do których w ten sposób wraca, nabierają wymiaru ontologicznego. Petrović, mogąc sobie na to pozwolić, zniekształca tym samym nieco mechanizm funkcjonowania wspomnień. „Stary człowiek - pisze Michał Kaczmarek — pokłada pełne zaufanie we wspomnieniach z młodości [...], ale jednocześnie przeczuwa, iż to, co pamięta, już nie istnieje obiektywnie, jest tylko dostępne w jego starczej pamięci i zniknie wraz z jego śmiercią, ostatecznie pogrąży się w nicości”" ${ }^{\prime \prime}$. W przypadku naszej bohaterki, to, co jeszcze pamięta, wciąż istnieje, ponieważ w jej świadomości wspomnienia mają byt realny, ich rzeczywistością jest bowiem przestrzeń książki, którą można wielokrotnie czytać.

Starzenie się i przemijanie Nataliji Dimitrijević Petrović ilustruje także motywem zapominania. Istotę samego zjawiska oraz wiele zagadnień związanych z naturą ludzkiej pamięci badał szczegółowo Douve Draaisma, który pisał między innymi, iż „wspomnienie może być mgliste bądź wyraźne, przyjemne lub bolesne, to, co zapominasz, jest tylko nieobecnością, czymś bez właściwości ani

${ }^{14}$ Chodzi tu o pamięć autobiograficzną (w odróżnieniu od np. pamięci prospektywnej, odnoszącej się do przyszłych planów, zamierzeń), odpowiedzialną za przechowywanie wspomnień dotyczących zdarzeń, doznań, odczuć z własnego życia, będącą swoistym rejestrem osobistych przeżyć.

15 S. de Beauvoir, Starość, przeł. Z. Styszyńska, Warszawa 2011, s. 409.

${ }^{16}$ M. Kaczmarek, O dobrodziejstwach pamięci starego człowieka. Oblicza starczej pamięci w wybranych tekstach literackich, [w:] Egzystencjalne doświadczenie starości w literaturze, red. A. Gleń, I. Jokiel, M. Szladowski, Opole 2008, s. 156. 
desygnatu" ${ }^{\prime 17}$. Zapominanie jest więc pierwszym krokiem w niebyt. Początkowo bohaterka traci pojedyncze wspomnienia, później zaczynają znikać całe ich grupy i szeregi, wspomnienia kilku, a z czasem i kilkunastu lat. Bohaterce coraz trudniej przywołać w pamięci choćby jeden dzień z całego okresu, który bezpowrotnie się zagubił, jakby nigdy nie istniał. Po zanikaniu wspomnień przychodzi czas na zapominanie słów.

Zaboravila sam... - mówi pani Natalija - Ne mogu da se setim... Nekada ne mogu da prizovem u pamćenje po nekoliko godina... Nekada mi je uspomena još kao živa... Ali, ne mogu da se dosetim reči kojima bih je izrazila... Tako, na vrh su mi jezika... Ipak, da ih prevalim, nisam kadra ${ }^{18}$.

Poprzez postać Nataliji Dimitrijević Goran Petrović pokazuje, jak życie człowieka jest nierozerwalnie związane $\mathrm{z}$ językiem. Zdolność posługiwania się nim to umiejętność nabyta, nie wrodzona. Wraz z wiekiem i doświadczeniem, jakie zdobywa człowiek, rozwija się także język, którego używa; poszerzają się pola semantyczne i leksykalne, po których stąpa, styl wypowiedzi zmienia się na bogatszy, bardziej precyzyjny. U Petrovicia relacja ta przedstawia się odwrotnie. To nie doświadczenie i wiek warunkują takie czy inne korzystanie z języka, lecz język determinuje określoną postawę człowieka i decyduje o jego istnieniu w świecie. Realizację tej koncepcji dostrzegamy wyraźnie w bohaterce powieści Sitničarnica ,kod srećne ruke”. Czas, jaki jeszcze jej pozostał, wyznacza język, którym się posługuje i wraz z zapominaniem przez nią kolejnych słów jej życie zaczyna dobiegać końca. Zapominanie przez bohaterkę języka ma również wpływ na możliwość czytania przez nią książek, a więc „odtwarzania wspomnień”. Czytanie jest bowiem całkowicie uzależnione od zdolności językowych (obok między innymi percepcyjnych, poznawczych, i pamięciowych ${ }^{19}$ ), które wraz w wiekiem ulegają degradacji. Człowiek istnieje tylko poprzez język, a nazywając, powołuje rzeczy do istnienia. Nie mając już zupełnie nic, nigdy nie zostaje w istocie z niczym, gdyż ,jezik je ono što nam uvek preostaje"20. Egzystencja ludzka kończy się więc dopiero z chwilą utraty języka. Nie potrafiąc przypomnieć sobie kolejnych słów, Natalija Dimitrijević sama coraz bardziej odchodzi w niepamięć i tak jak materialny byt wewnętrznego świata fikcji zależy od jego tekstowej reprezentacji, tak istnienie Natalii zależne było od języka, a jego całkowite zapomnienie wyznaczyło moment śmierci bohaterki. „Natalija Dimitrijević je umrla u utorak izjutra, [...] nije mogla da se seti nijedne reči, poćutala je oko četvrt časa, uporno gledajući horizont, prividni spoj zemlje i neba. A onda je od čekanja odustala" ${ }^{21}$.

17 D. Draaisma, Księga zapominania, przeł. R. Pucek, Warszawa 2012, s. 10.

${ }^{18}$ G. Petrović, Sitničarnica..., s. 232.

19 Szerzej na ten temat zob. I. Stuart-Hamilton, Psychologia starzenia się. Wprowadzenie, rozdz. 4, Starzenie się i język, przeł. A. Błachnio, Poznań 2006.

${ }^{20}$ G. Petrović, Sitničarnica..., s. 217.

${ }^{21}$ Ibidem, s. 325. 
Słowa powołują do istnienia i wraz z ich zniknięciem znika także sam człowiek. Nadając czemuś postać zwerbalizowaną, nadajemy mu jednocześnie wymiar ontologiczny. W przeciwieństwie do Platońskiej myśli o bytach idealnych, istniejących niezależnie od czynnika ludzkiego, u Petrovicia nic nie istnieje niezależnie od świadomości bohaterów w postaci idealnej „,samo w sobie”. Bohaterka przestaje istnieć na poziomie językowym i tym samym znika również z kart powieści. Język staje się tym samym najważniejszym instrumentem w tworzeniu przestrzeni prozy Petrovicia i, jak zauważa Šaponja, „minijature stvarnosti njegovog sveta dešavaju se u jeziku koji biva jedinom stvarnošću" 22 . Warto w tym miejscu odwołać się raz jeszcze do słów wspomnianego wcześniej holenderskiego badacza. Douve Draaisma rozpoczyna jeden ze swoich esejów stwierdzeniem: „Czy nasze życie zakończy się utratą pamięci, to się dopiero okaże, pewne jest jednak, że od utraty pamięci się zaczyna"23. Natalija Dimitrijević może być literackim przykładem na to, że utrata pamięci, a co za tym idzie zapomnienie języka, bezwarunkowo kończy nasze życie.

Tajemnica piękna starości sympatycznych i dobrotliwych bohaterów Gorana Petrovicia kryje się także w tym, że autor przekonuje czytelnika, iż postaciom tym udało się przekroczyć ciasne granice fizykalnego czasu i przestrzeni. Staruszkowie z tomu opowiadań Ostrvo i okolne priče żyją we własnym świecie zbudowanym z marzeń sennych, natomiast Natalija Dimitrijević w świecie książek, które czyta. Wszyscy oni zdają sobie sprawę z przemijania tych światów, kurczenia się przestrzeni snu, zapominania wspomnień i języka. Żyją w świecie, który zanika i umiera wraz z nimi. Petrović pokazuje, że starość to stan poetyckiego (i umysłowego) uwolnienia się od rzeczywistości. Wyjście poza czas natomiast, a więc osiągnięcie przez jednostkę takiego stanu, w którym czas przestaje mieć jakiekolwiek znaczenie, możliwe jest dzięki (sic!) postępującemu zanikowi pamięci i osłabieniu zdolności kognitywnych starszych bohaterów. Simone de Beauvoir pisze, że „w ludzkiej rzeczywistości istnieć oznacza umiejscowić się w czasie" 24 i dodaje zaraz, że „wiek zmienia nasze podejście do czasu. Z biegiem lat nasza przyszłość się skraca, natomiast przeszłość nabiera coraz większego ciężaru. Starca można zdefiniować jako osobę, która ma za sobą długie życie, a przed sobą bardzo skróconą perspektywę życia"25. Kiedy zatem w podeszłym wieku przeszłość zaczyna splatać się z teraźniejszością, a o przyszłości przestaje się zupełnie myśleć, człowiek wyzwala się z kajdan czasu i zaczyna istnieć poza nim. Bohaterowie Petrovicia nie funkcjonują w „ludzkiej rzeczywistości” lecz, dzięki odpowiednim zabiegom językowo-stylistycznym, w rzeczywistości onirycznej, zmetaforyzowanej i odrealnionej.

22 N. Šaponja, Kartografija metafora i slika kao prozračnost prozora nestvarnog, [w:] idem, Bedeker sumnje. 13 savremenih proznih pisaca, Beograd 1997, s. 169.

${ }^{23}$ D. Draaisma, Dlaczego życie ptynie szybciej, gdy się starzejemy: o pamięci autobiograficznej, przeł. E. Jusewicz-Katler, Warszaw 2006, s. 21.

${ }^{24}$ S. de Beauvoir, Starość..., s. 409.

25 Ibidem. 
Podsumowując, można powiedzieć, że starość, którą tak rzadko naznacza autor swoich bohaterów, ukazana jest u Petrovicia w niezwykle piękny sposób, ubrana w kapelusze i niciane rękawiczki, wygrzewająca stare kości w gęstych promieniach słońca na ganku. Pisarz wykorzystuje język, by z jednej strony zmetaforyzować i wyidealizować oniryczną scenerię rzeczywistości bohaterów, z drugiej zaś, by wskazać na jego ontologiczny charakter. O stylu Petrovicia Mihajlo Pantić pisze, że język jego utworów jest odbiciem osobowości i charakteru pisarza, jest „, i bajokvit, i melodičan, i diskretno duhovit, i gozben, i jezgrovit, i snevan, [...] ima imensku moć i snagu prvotnosti, njime se postvaruje jedan nestvarni svet, njime se poetizuje jedan realni svet" ${ }^{26}$. Wersja liryczno-onirycznej prozy autora z Kraljeva z pełnym rekwizytorium chwytów i technik literackich „,daje novu snagu poetskojezičke imaginacije: njegov fantastički svet se u ravni književnog teksta ponaša apsolutno realno, on je više od toga, realniji od zdravorazumske realnosti i njoj je pretpostavljen"27. Poprzez metaforyzację języka pisarzowi udało się także upoetyzować jakże mało poetycką starość, towarzyszącą jej chorobę i samo odchodzenie.

\section{Bibliografia}

Arystoteles, Retoryka. Poetyka, przeł. H. Podbielski, Warszawa 1988.

Beauvoir de S., Starość, przeł. Z. Styszyńska, Warszawa 2011.

Draaisma D., Dlaczego życie plynie szybciej, gdy się starzejemy: o pamięci autobiograficznej, przeł. E. Jusewicz-Katler, Warszawa 2006.

Draaisma D., Księga zapominania, przeł. R. Pucek, Warszawa 2012.

Kaczmarek M., O dobrodziejstwach pamięci starego człowieka. Oblicza starczej pamięci w wybranych tekstach literackich, [w:] Egzystencjalne doświadczenie starości w literaturze, red.

A. Gleń, I. Jokiel, M. Szladowski, Opole 2008.

McHale B., Powieść postmodernistyczna, przeł. M. Płaza, Kraków 2012.

Nowak-Bajcar S., Mapy czasu. Serbska proza postmodernistyczna wobec wyzwań epoki, Kraków 2010.

Okopień-Sławińska A., Metafora bez granic, [w:] Studia o metaforze, 2, red. M. Głowiński, A. Okopień-Sławińska, Wrocław 1983.

Pantić M., Goran Petrović, Postvarivanje mašte, rastakanje sveta, „Letopis Matice srpske”, jul-avgust, 1998.

Pawełczyk K., Starość w czasie i przestrzeni. Modele starości na wybranych przykładach kulturowych, [w:] Starość: doświadczenie egzystencjalne, temat literacki, metafora kultury, seria I. Rozpoznania, red. A. Janicka, E. Wesołowska, G. Kowalski, Białystok 2013.

Petrović G., Ostrvo i okolne priče, Beograd 2002.

Petrović G., Sitničarnica „Kod Srećne Ruke”, Beograd 2005.

Šaponja N., Kartografija metafora i slika kao prozračnost prozora nestvarnog, [w:] idem, Bedeker sumnje. 13 savremenih proznih pisaca, Beograd 1997.

Stuart-Hamilton I., Psychologia starzenia się. Wprowadzenie, rozdz. 4., Starzenie się i język, przeł. A. Błachnio, Poznań 2006.

${ }^{26}$ M. Pantić, Goran Petrović, Postvarivanje mašte, rastakanje sveta, „Letopis Matice srpske", jul-avgust, 1998, s. 186.

${ }^{27}$ Ibidem, s. 187. 


\section{The beauty of old age. Poetic image of passing in Goran Petrovic's prose}

\section{Summary}

The aim of the article was to present the beauty of aging heroes living in a dreamlike and idealized worlds of Goran Petrovic's prose, and to reveal the mechanism of beautifying the aging process itself by reffering to folklore, playing with stereotypes, and using strongly metaphoric language. Presented paper focuses on Petrovic's interesting ways of showing the beauty hidden in old age, also pointing to forgetting names and words as the most important determinant of aging what indicates a close connection between human existence and language (ontological status of language).

Keywords: metaphoric prose, memory, forgetting, ontological status of language, oneiric prose

\section{Lepota starosti. Poetska slika upokojenja u prozi Gorana Petrovića}

\section{Rezime}

Cilj ovog članka je da se predstavi lepotu starenja junaka koji žive u oniričkim i idealiziranim svetovima proze Gorana Petrovića, i da se otkrije mehanizam ulepšavanja samog procesa starenja igrajući sa stereotipima, koristeći folklor i snažno metaforički jezik. Predstavljen rad usredotočuje pažnju na Petrovićev zanimljiv način pokazivanja lepote skrivene u starosti, isto i na zaboravljanje imena i reči kao najvažnije determinante starenja što ukazuje na blisku vezu između ljudskog postojanja i jezika (ontološki status jezika).

Ključne reči: metaforička proza, pamet, zaboravljanje, ontološki status jezika, onirička proza 